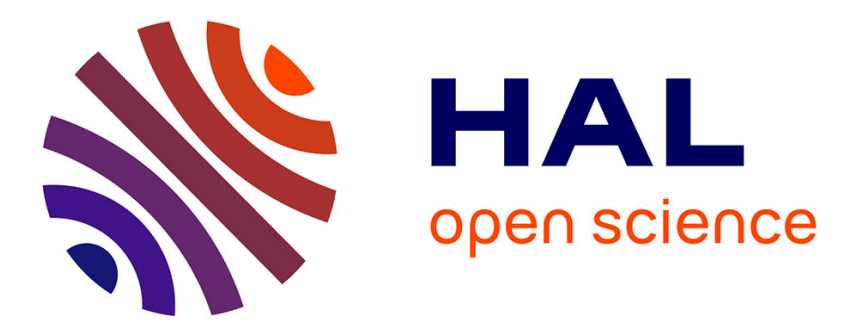

\title{
GRIP Deuterium Excess Reveals Rapid and Orbital-Scale Changes in Greenland Moisture Origin
}

V. Masson-Delmotte, J. Jouzel, A. Landais, M. Stievenard, S.J. Johnsen, J.W.C. White, M. Werner, A. Sveinbjörnsdottir, K. Fuhrer

\section{- To cite this version:}

V. Masson-Delmotte, J. Jouzel, A. Landais, M. Stievenard, S.J. Johnsen, et al.. GRIP Deuterium Excess Reveals Rapid and Orbital-Scale Changes in Greenland Moisture Origin. Science, 2005, 309 (5731), pp.118-121. 10.1126/SCIENCE.1108575 . hal-03101216

\section{HAL Id: hal-03101216 https://hal.science/hal-03101216}

Submitted on 2 Jul 2021

HAL is a multi-disciplinary open access archive for the deposit and dissemination of scientific research documents, whether they are published or not. The documents may come from teaching and research institutions in France or abroad, or from public or private research centers.
L'archive ouverte pluridisciplinaire HAL, est destinée au dépôt et à la diffusion de documents scientifiques de niveau recherche, publiés ou non, émanant des établissements d'enseignement et de recherche français ou étrangers, des laboratoires publics ou privés. 


\title{
R E P O R T S
}

SSTs in individual ocean basins may have less influence on Sahel rainfall than the tropics as a whole.

18. A. Gill, Q. J. R. Meteorol. Soc. 106, 447 (1980).

19. Y. Kushnir et al., J. Clim. 15, 2233 (2002).

20. M. Rodwell, C. Folland, Ann. Geophys. 46, 47 (2003).

21. B. Dong, R. Sutton, Geophys. Res. Lett. 29, 1728 (2002).

22. R. Zhang, T. Delworth, J. Clim., in press.

23. C. Cassou, L. Terray, A. Phillips, J. Clim., in press.

24. S. Gray, L. Graumlich, J. Betancourt, G. Pederson, Geophys. Res. Lett. 31, L12205 (2004); 10.1029/ $2004 G$ L019932.

25. P. Stott, D. Stone, M. Allen, Nature 432, 610 (2004).
26. M. Schlesinger, N. Ramankutty, Nature 367, 723 (1994).

27. J. Houghton et al., Climate Change 2001: The Scientific Basis (Cambridge Univ. Press, Cambridge, 2001).

28. C. Folland, J. Owen, M. Ward, A. Colman, J. Forecasting 10, 21 (1991).

29. N. Rayner et al., J. Geophys. Res. 108, 4407; 10.1029/2002JD002670 (2003).

30. R.T.S. is supported by a Royal Society University Research Fellowship. D.L.R.H. is supported by the NERC Centres for Atmospheric Science. We are grateful to colleagues at the Met Office Hadley Centre for providing the HadISST and HadSLP data sets and results from the C20 global SST experiments. We thank J. Hurrell for valuable comments on the paper.

\section{Supporting Online Material}

www.sciencemag.org/cgi/content/full/309/5731/115/ DC1

Materials and Methods

Figs. S1 to S3

References

6 January 2005; accepted 20 May 2005 10.1126/science. 1109496

\section{GRIP Deuterium Excess Reveals Rapid and Orbital-Scale Changes in Greenland Moisture Origin}

\author{
V. Masson-Delmotte, ${ }^{1 *}$ J. Jouzel, ${ }^{1}$ A. Landais, ${ }^{1}$ M. Stievenard, \\ S. J. Johnsen, ${ }^{2,3}$ J. W. C. White, ${ }^{4}$ M. Werner, ${ }^{5}$ \\ A. Sveinbjornsdottir, ${ }^{3}$ K. Fuhrer ${ }^{6}$
}

\begin{abstract}
The Northern Hemisphere hydrological cycle is a key factor coupling ice sheets, ocean circulation, and polar amplification of climate change. Here we present a Northern Hemisphere deuterium excess profile covering one climatic cycle, constructed with the use of $\delta^{18} \mathrm{O}$ and $\delta \mathrm{D}$ Greenland Ice Core Project (GRIP) records. Past changes in Greenland source and site temperatures are quantified with precipitation seasonality taken into account. The imprint of obliquity is evidenced in the site-to-source temperature gradient at orbital scale. At the millennial time scale, GRIP source temperature changes reflect southward shifts of the geographical locations of moisture sources during cold events, and these rapid shifts are associated with large-scale changes in atmospheric circulation.
\end{abstract}

The atmospheric water cycle plays a key role in climate change. At various time scales, changes in atmospheric moisture transport are intimately involved in key processes within the climate system, such as the growth of ice sheets or the freshwater budget of the ocean. Here we use an integrated tracer of the water cycle, the isotopic composition of the ice preserved in Greenland, to decipher changes in Greenland moisture origin over the last glacial cycle.

Water stable isotopes ratios $\left(\delta^{18} \mathrm{O}\right.$ or $\left.\delta \mathrm{D}\right)$ from polar ice cores are commonly used as past temperature proxies $(1,2)$, a function made possible by the progressive distillation of heavy water isotopes when air masses cool toward

${ }^{1}$ IPSL/Laboratoire des Sciences du Climat et de l'Environnement (LSCE), UMR CEA-CNRS, CEA Saclay, 91191 Gif-sur-Yvette, France. ${ }^{2}$ Department of Geophysics, Juliane Maries Vej 30, University of Copenhagen, DK-2100 Copenhagen, Denmark. ${ }^{3}$ Science Institute, University of Iceland, Dunhaga 3, Reykjavik 107, Iceland. ${ }^{4}$ Institute of Arctic and Alpine Research Institute and Department of Geological Sciences, Campus Box 450, University of Colorado, Boulder, CO 80309, USA. ${ }^{5}$ Max Planck Institute for Biogeochemistry, Postbox 1001 64, D-07701 Jena, Germany. ${ }^{6}$ Physics Institute, University of Bern, Sidlerstrasse 5, CH-3012 Bern, Switzerland.

${ }^{*}$ To whom correspondence should be addressed. E-mail: valerie.masson@cea.fr polar regions (3-5). Comparison of Greenland temperature $\left(T_{\text {site }}\right)$ values derived from ice $\delta^{18} \mathrm{O}$ using the observed modern spatial gradient with alternative paleothermometry methods yields a systematic underestimation of past surface annual mean temperature changes, both at glacial-interglacial $(6-8)$ and rapid-events time scales (9-13). Such discrepancies are thought to arise from variability in the Northern Hemisphere hydrological cycle, either from changes in moisture source areas (14) or from changes in the seasonality of precipitation $(15,16)$.

We used high-precision continuous water stable isotope measurements made on the GRIP ice core (table S1) to calculate a Northern Hemisphere deuterium excess $d=[\delta \mathrm{D}-(8 \times$ $\left.\left.\delta^{18} \mathrm{O}\right)\right]$ profile covering one climatic cycle (17). This deuterium excess record, together with a method to account for changes in precipitation seasonality, was then used to quantify past changes in Greenland moisture source temperature.

Figure 1 shows both $\delta^{18} \mathrm{O}$ and deuterium excess profiles for the last $\sim 100,000$ years (i.e., excluding the lowest part of the profiles characterized by ice flow disturbances) (18). The excess profile reveals well-defined features at glacial-interglacial time scales, with a 5 per mil (\%o) increase during the last climatic transition (5), as well as for DansgaardOeschger $(\mathrm{D} / \mathrm{O})$ events characterized by large (up to $5 \%$ ) excess changes, in antiphase with $\delta^{18} \mathrm{O}$ changes. Similar rapid excess changes are also recorded in the North Greenland Ice Core Project (NorthGRIP) ice core for D/O events 18 to 20 (13). Such deuterium-excess variations essentially result from the fact that, with respect to equilibrium processes, kinetic isotopic effects play a much larger relative role for $\delta^{18} \mathrm{O}$ than for $\delta \mathrm{D}$. In turn, deuterium excess in polar snow, $d_{\text {snow }}$, is largely driven by nonequilibrium processes (i.e., evaporation at the ocean surface and condensation of water vapor when snow forms). Deuterium excess in water vapor over the ocean is mainly influenced by sea surface isotopic composition, sea surface temperature (SST), source temperature $\left(T_{\text {source }}\right)$, and relative humidity. This imprint of oceanic conditions (here considered only in terms of $T_{\text {source }}$ ) in the moisture source areas is largely preserved in the deuterium excess signal recorded in polar snow (19). In turn, whereas $\delta_{\text {snow }}\left(\delta^{18} \mathrm{O}\right.$ or $\left.\delta \mathrm{D}\right)$ depends primarily on local temperature $T_{\text {site }}$ and to a lesser degree on $T_{\text {source }}$, one can show that the opposite is true for $d_{\text {snow }}(20,21)$.

Combining $\delta^{18} \mathrm{O}$ and deuterium excess profiles allows us to estimate both $T_{\text {site }}$ and $T_{\text {source. This dual approach, based on the }}$ inversion (22) of a dynamically simple isotopic model (23), is now used for interpreting isotopic measurements performed on Antarctic cores (24-26). Although useful for the last millennium and for the Holocene in Greenland $(20,27)$, this methodology leads to unrealistic results when applied directly to the long-term GRIP data (21). We show here that this difficulty can be overcome if this inversion accounts for the seasonality of snow precipitation, as suggested by general circulation model simulations. This allows us to interpret the $\delta^{18} \mathrm{O}$ or $\delta \mathrm{D}$ GRIP data in terms of $T_{\text {site }}$ and $T_{\text {source }}$ changes in a consistent way, both for glacial-interglacial changes and for $\mathrm{D} / \mathrm{O}$ events, thus providing high-resolution information on the source conditions and the reorganizations of the water cycle during slow and rapid climatic changes.

Seasonal characteristics are relatively well known for central Greenland's present-day climate. Field observations suggest a year- 


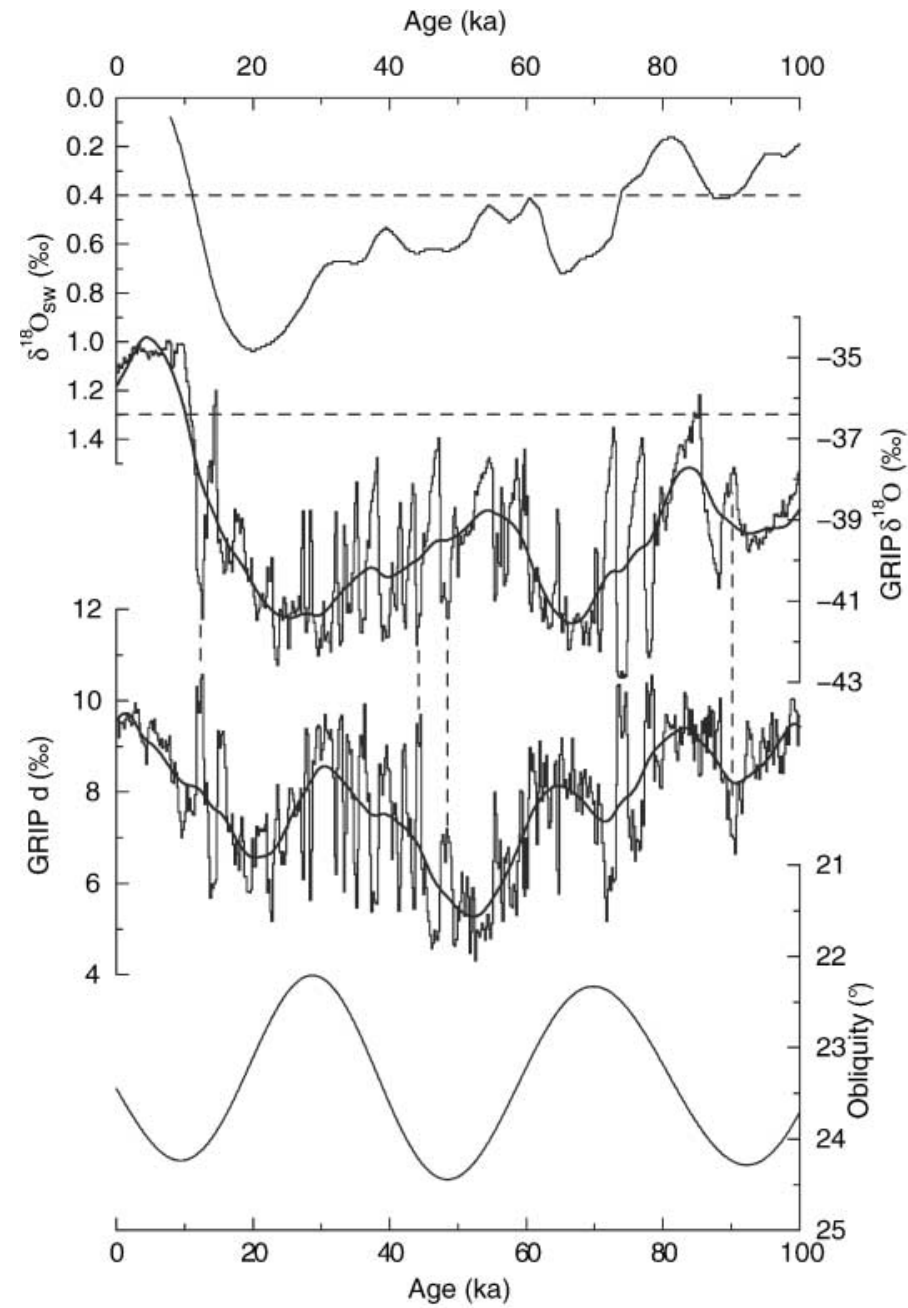

Fig. 1 (left). From top to bottom: ice volume indicated by seawater $\delta^{18} \mathrm{O}_{\text {sw }}$ (31); 200-year resampled GRIP $\delta^{18} \mathrm{O}$ and deuterium excess $d$ (bold lines represent isotopic profiles smoothed using the first two components of a singular spectral analysis, which represents a low-pass filter below 10,000 years); and obliquity (43). Analytical precisions are $\pm 0.05 \%$ for $\delta^{18} \mathrm{O}$ and $\pm 0.50 \%$ o for $\delta D$, resulting in a precision of $\pm 0.64 \%$ for deuterium excess. Horizontal dashed lines identify thresholds $T_{1}$ and $T_{2}$ used for the seasonality correction. Vertical lines point to selected rapid events (from left to right: Younger Dryas, cold phases of D/O events 11, 12, and 22). Fig. 2 (right). From top to bottom: $\log (\mathrm{Ca})(39) ; 200$-year reconstructed site-to-source temperature gradient (black solid line) and obliquity fluctuations (black dashed line); site temperature $\left(\Delta T_{\text {site }}\right)$ reconstructed using various methods

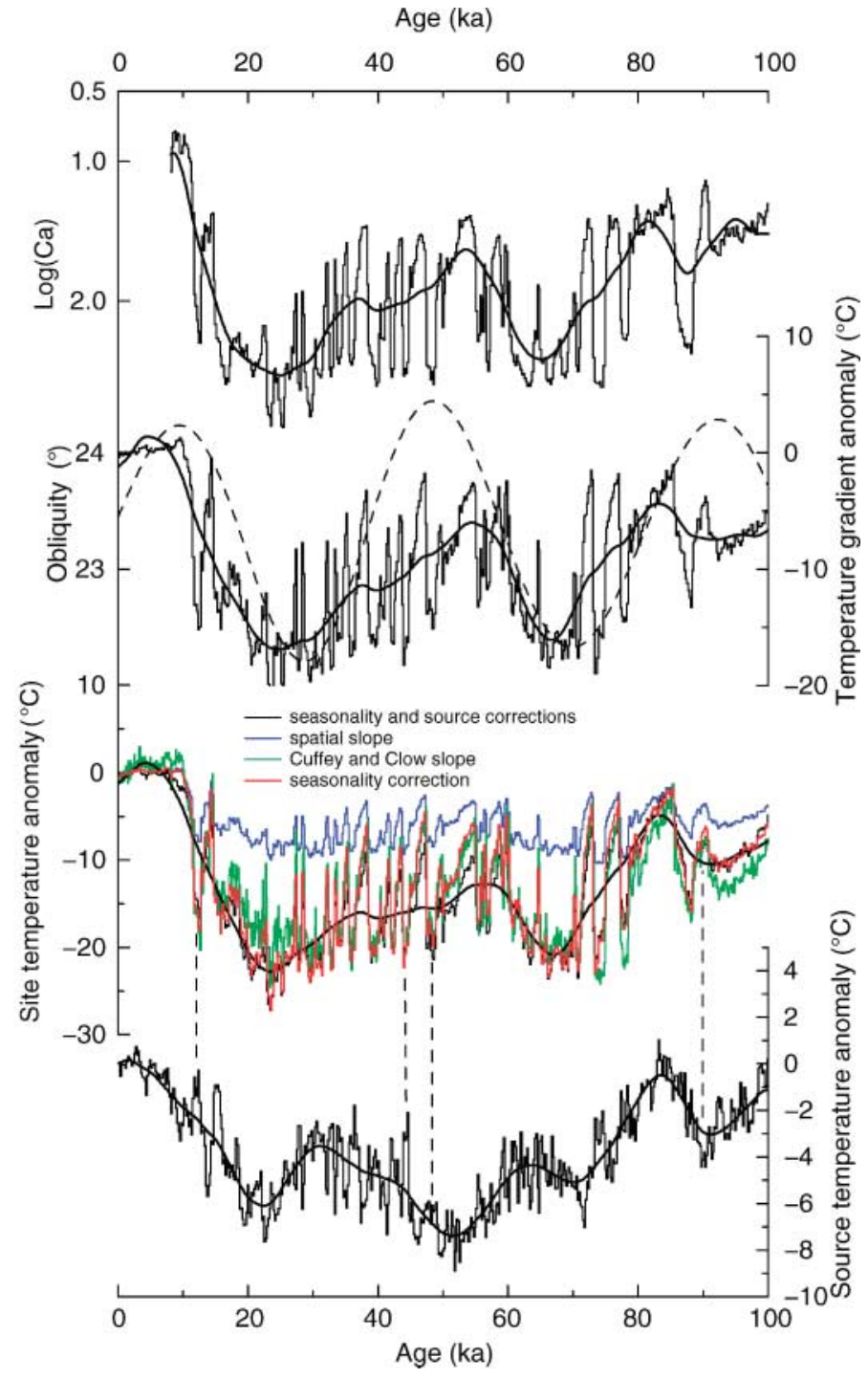

[spatial slope without seasonality correction, blue; our inversion with seasonality correction but without source correction, red; our full isotopic inversion with seasonality correction, black; the use of a constant slope fitting with the LGM borehole estimate (32), green]; source temperature $\left(\Delta T_{\text {source }}\right)$ reconstruction from full inversion. Results are displayed as anomalies from modern conditions (present-day GRIP site temperature is $\sim-32^{\circ} \mathrm{C}$ and GRIP source temperature is $\sim 20^{\circ} \mathrm{C}$ ). Bold lines represent smoothed reconstructions as for Fig. 1. round snowfall at Summit with a slightly larger winter half-year accumulation due to intense episodic storms (28). The seasonal variations are strongly imprinted in $\delta^{18} \mathrm{O}_{\text {snow }}$, which closely follows the temperature changes. As shown by detailed shallow ice core and pit studies, there is also a well-documented $d_{\text {snow }}$ seasonal cycle that lags variations in temperature, $\delta \mathrm{D}$, and $\delta^{18} \mathrm{O}$ by $\sim 2$ to 3 months $(5,29)$. This delay is probably due to the thermal inertia of the ocean, which results in a 2- to 3-month lag between mid-latitude ocean surface temperature and continental surface air temperature.

In contrast, glacial conditions inhibit winter snowfall because of the modification of the stationary waves and the southward deviation of the winter storm tracks by (i) the Laurentide ice sheet, and (ii) the modified latitudinal ocean surface temperature gradients and increased extent of sea ice (30). Modeling results suggest a large change in precipitation seasonality toward a dominant summer contribution $(15,16)$. We also expect an enhanced $\delta_{\text {snow }}$ seasonal amplitude due to increased glacial Greenland continentality. The $\sim 2$ - to 3-month lag of the deuterium excess cycle, thermally driven, should be essentially unchanged.

A detailed sensitivity analysis shows that a simple half-year (summer-winter) approach is well adapted to account for these seasonality changes for reconstructing site and source temperature records $(21)$. Whereas the wintersummer difference is large for $\delta_{\text {snow }}$, it is small (less than 1\%o) for the deuterium excess because of its seasonal lag. Hence, seasonality has a strong impact on estimates of $T_{\text {site }}$ but a much weaker influence on $T_{\text {source }}$, as these two variables are driven by $\delta_{\text {snow }}$ and $d_{\text {snow }}$, respectively. The glacial decrease in winter precipitation results in amplified seasonally corrected isotopic signals by a factor that is also influenced by the changes in the summerwinter isotopic amplitude [(21), equation 5]. We account for seasonality when two conditions linked with sea-ice extent and Laurentide ice sheet size are fulfilled: (i) Sea-ice extent is assumed to inhibit local moisture supply when the site temperature is below a certain threshold $T_{1}$ directly derived from the ice $\delta^{18} \mathrm{O}$ record, and (ii) to reflect the fact that the winter moisture advection is related to the size 


\section{R E P O R T S}

of the Laurentide ice sheet, we account for seasonality changes only when the Laurentide is large enough. We use here a second threshold, $T_{2}$, derived from the marine benthic $\delta^{18} \mathrm{O}$ sea level record, itself closely related to the size of the Laurentide (31). Ensemble simulations of seasonality correction and full isotopic inversion are then performed within a wide range of correction coefficients. Obtaining a consistency with robust estimates of site temperature amplitudes obtained with independent methods (Table 1) for the Last Glacial Maximum (LGM), Younger Dryas, BøllingAllerød, and $\mathrm{D} / \mathrm{O}$ events 12 and 19 constrains the thresholds $T_{1}\left(\delta^{18} \mathrm{O}\right.$ of ice $<-36.4 \%$ ) and $T_{2}$ (ocean $\delta^{18} \mathrm{O}<0.4 \%$ ), and also the amplification coefficient, to a value of 2.0.

The resulting site and source fluctuations are shown in Fig. 2, showing a warming of $\sim 21.5^{\circ} \mathrm{C}$ from the LGM to the Holocene [estimate based on the 2000-year period centered at 21,000 years ago (21 ka)]. Our reconstruction for $\mathrm{D} / \mathrm{O}$ events 18 and 20 is also consistent with independent estimates of site temperature changes obtained using gas fractionation (performed in this latter case on the NorthGRIP core located $300 \mathrm{~km}$ northnorthwest of the GRIP site) (Table 1). Figure 2, which compares various approaches to reconstructing $T_{\text {site }}$ changes from water isotopes, clearly shows the importance of accounting for seasonality. However, there is also a significant influence of the source temperature (full inversion, black curve), which results in a systematic shift of the warm part of each $\mathrm{D} / \mathrm{O}$ event toward colder temperatures. This is due to the antiphase between the $\delta^{18} \mathrm{O}$ (or $\delta \mathrm{D}$ ) and excess rapid variations: When Greenland is warm, the moisture source is colder, and if this is not corrected for, temperature estimates will be too cold (and vice versa). Neglecting changes in moisture source and using a constant temporal isotope-temperature slope of half the spatial slope (32) is therefore inadequate to reconstruct past Greenland temperatures from $\delta^{18} \mathrm{O}$ and could induce an overestimation of some rapid-events temperature change by up to $40 \%$ (Fig. 2 and Table 1). In other words, the apparent isotope-temperature slope varies at all time scales (13).

Table 1. Estimates of site temperature changes and comparison with two methods to estimate temperature changes using the water stable isotopes from GRIP ice cores. $\Delta T_{\text {site }}$ full inversion, results of the full isotopic inversion after seasonality correction; $\Delta T_{\text {site }}$ constant slope, estimate from ice $\delta^{18} \mathrm{O}$ only, with a constant slope before $8 \mathrm{ka}(32)$.

\begin{tabular}{lclrr}
\hline Period & $\begin{array}{c}\text { Temperature } \\
\text { change }\end{array}$ & \multicolumn{1}{c}{ Method } & $\begin{array}{r}\Delta T_{\text {site }} \text { full } \\
\text { inversion }\end{array}$ & $\begin{array}{c}\Delta T_{\text {site }} \text { constant } \\
\text { slope }\end{array}$ \\
\hline Last Glacial Maximum & $-23^{\circ} \pm 3^{\circ} \mathrm{C}(8)$ & Borehole thermometry & $-21.5^{\circ} \pm 3^{\circ} \mathrm{C}$ & $-17.9^{\circ} \mathrm{C}$ \\
Bølling & $11^{\circ} \pm 3^{\circ} \mathrm{C}(44)$ & Gas fractionation & $10.9^{\circ} \pm 3^{\circ} \mathrm{C}$ & $13.9^{\circ} \mathrm{C}$ \\
Younger Dryas & $10^{\circ} \pm 4^{\circ} \mathrm{C}(9)$ & Gas fractionation & $9.7^{\circ} \pm 3^{\circ} \mathrm{C}$ & $11.1^{\circ} \mathrm{C}$ \\
D/O 12 & $12^{\circ} \pm 3^{\circ} \mathrm{C}(12)$ & Gas fractionation & $13.9^{\circ} \pm 3^{\circ} \mathrm{C}$ & $13.1^{\circ} \mathrm{C}$ \\
D/O 18 & $11^{\circ} \pm 3^{\circ} \mathrm{C}(13)$ & Gas fractionation & $9.8^{\circ} \pm 3^{\circ} \mathrm{C}$ & $11.4^{\circ} \mathrm{C}$ \\
D/O 19 & $16^{\circ} \pm 3^{\circ} \mathrm{C}(11,13)$ & Gas fractionation & $17.1^{\circ} \pm 3^{\circ} \mathrm{C}$ & $20.2^{\circ} \mathrm{C}$ \\
D/O 20 & $11^{\circ} \pm 3^{\circ} \mathrm{C}(13)$ & Gas fractionation & $11.7^{\circ} \pm 3^{\circ} \mathrm{C}$ & $16.7^{\circ} \mathrm{C}$ \\
\hline
\end{tabular}

change reconstructed here. A detailed inspection of $\Delta T_{\text {source }}$ (Fig. 2), which resembles the initial deuterium excess record (Fig. 1), also points to important differences at millennial time scales. High-resolution North Atlantic SST records exhibit rapid changes generally in phase with Greenland $\mathrm{D} / \mathrm{O}$ events recorded in $T_{\text {site, }}$, whereas $\Delta T_{\text {source }}$ reconstruction suggests an out-of-phase relation between $T_{\text {source }}$ and $T_{\text {site }}$ during rapid changes.

Our proposed interpretation is that these noticeable differences (amplitude of LGM-tomodern changes and millennial-scale events) result from drastic changes in the polar front, the geographical location of Greenland's main moisture sources, and the atmospheric water cycle during glacial times (5). When Greenland is cold and surrounded by an extensive sea ice cover, mid-latitude oceans are much colder than today and cannot provide much moisture to Greenland. Evaporation is, however, maintained at lower subtropical and tropical locations, providing precipitation in central Greenland largely in summer. Typically, a southward moisture source shift of $5^{\circ}$ in latitude is compatible both with the LGM $\Delta T_{\text {site }}$ values and with local summer SST reconstructions. This is also consistent with temperature and salinity latitudinal profiles estimated from marine sediments, reflecting the shift of the dominant evaporative areas during rapid events (38).

Such a large-scale reorganization of the hydrological cycle at both orbital and millennial time scales is indirectly confirmed by the calcium composition of GRIP ice, a parameter reflecting (i) the strength of GRIP dust sources mainly provided by Chinese loess areas, and (ii) the efficiency of dust transport to Greenland (39). The strong correlation between $\log (\mathrm{Ca})$ and $\delta^{18} \mathrm{O}$ of ice was previously noted (39), but the similarity is even better with this reconstructed site-to-source temperature gradient $\left(R^{2}=0.86\right.$ at 100 -year time step and $R^{2}=0.88$ at 5000-year time step between 8 and $100 \mathrm{ka}$ ). In particular, a warmer site and a colder source at $\sim 50$ to 55 ka result in a decreased meridional temperature gradient, exactly at the time of minimum calcium concentration. The meridional temperature gradient also shows a 40,000-year modulation paralleling obliquity fluctuations (Fig. 1). We have already pointed out that mean annual insolation, and thus obliquity, strongly controls the meridional atmospheric circulation. We suggest that they also indirectly control the strength of the dust source: A larger obliquity should correspond to a decreased annual mean tropical ocean temperature and an increased land-sea contrast in summer, and could enhance the summer monsoons, thereby decreasing the continental dust sources.

Our interpretation of the $\delta^{18} \mathrm{O}$ and $d$ GRIP data provides a consistent picture of changes occurring over the last 100,000 years in Greenland and in the North Atlantic. Our findings confirm model results by showing that 
when seasonality is accounted for, reasonable local temperature estimates can be drawn from the GRIP isotopic record; the correction due to source temperature changes is of lesser importance at glacial-interglacial scales than during rapid events. Moreover, the comparison between our estimate of $\Delta T_{\text {source }}$ and available North Atlantic sediment-based SST reconstructions suggests that large changes in geographical moisture source location occur both at the orbital and millennial scales. We show that $\Delta T_{\text {source }}$ reflects obliquity changes and that $\Delta T_{\text {source }}$ and $\Delta T_{\text {site }}$ are of opposite sign, both at orbital and millennial time scales. The influence of obliquity on deuterium excess and moisture origin, already identified for Antarctica, is confirmed for Greenland. When cold conditions prevail in the mid- and high latitudes, the moisture origin shifts to milder southward locations (5). Finally, we point to striking similarities between the calcium-dust records and the site-to-source temperature gradient; both are strongly modulated by obliquity, and the coupled climate model results suggest that obliquity could be linked with dust source areas through the land-sea temperature contrast. At the millennial time scale, the site-to-source temperature fluctuations highlight large-scale changes in atmospheric circulation, which is consistent with the observation of simultaneous rapid climate changes at polar, temperate, and tropical latitudes (40) also recorded in Greenland ice chemistry and methane fluctuations (41). Modeling studies have indeed shown that Northern Hemisphere storm tracks are influenced not only by the topography of the ice sheets but also by the sea-ice extent and the meridional temperature gradients (30).

Such large changes in the atmospheric hydrological cycle and associated climate feedbacks are not fully represented in the intermediatecomplexity climate models commonly used to understand the mechanisms of abrupt events. Nonetheless, they could play a key role in the generation of instabilities of the ice sheets and the ocean circulation, amplified by changes in sea-ice extent, as has been suggested for the last glacial inception (42).

\section{References and Notes}

1. J. Jouzel et al., Nature 329, 403 (1987).

2. W. Dansgaard et al., Nature 364, 218 (1993).

3. W. Dansgaard, Tellus 16, 436 (1964).

4. C. Lorius, L. Merlivat, in Isotopes and Impurities in Snow and Ice: Proceedings of the Grenoble Symposium Aug./Sep. 1975 (International Association of Hydrological Sciences, Vienna, 1977), pp. 125-137.

5. S. Johnsen, W. Dansgaard, J. White, Tellus 41B, 452 (1989).

6. S. J. Johnsen, D. Dahl-Jensen, W. Dansgaard, N. Gundestrup, Tellus 47B, 624 (1995)

7. K. M. Cuffey et al., Science 270, 455 (1995).

8. D. Dahl-Jensen et al., Science 282, 268 (1998).

9. J. Severinghaus, T. Sowers, E. J. Brook, R. B. Alley, M. Bender, Nature 391, 141 (1998).

10. J. P. Severinghaus, E. Brook, Science 286, 930 (1999).

11. C. Lang, M. Leuenberger, J. Schwander, J. Johnsen, Science (1999).

12. A. Landais et al., Earth Planet. Sci. Lett. 225, 221 (2004).
13. A. Landais et al., Geophys. Res. Lett. 31, L22211 (2004).

14. E. A. Boyle, Geophys. Res. Lett. 24, 273 (1997).

15. G. Krinner, C. Genthon, J. Jouzel, Geophys. Res. Lett. 24, 2825 (1997)

16. M. Werner, U. Mikolajewicz, M. Heimann, G. Hoffmann Geophys. Res. Lett. 27, 723 (2000)

17. J. Jouzel et al., paper presented at the meeting of the European Geophysical Society, Nice, France, 6 to 11 April 2003.

18. A. Landais et al., J. Geophys. Res. 108, D06103 (2004)

19. A. Armengaud, R. D. Koster, J. Jouzel, P. Ciais, J. Geophys. Res. 103, 8947 (1998).

20. V. Masson-Delmotte et al., J. Geophys. Res., in press.

21. See supporting data on Science Online.

22. V. Masson-Delmotte, B. Stenni, J. Jouzel, Holocene 14, 145 (2004).

23. P. Ciais, J. Jouzel, J. Geophys. Res. 99, 16793 (1994)

24. B. Stenni et al., Science 293, 2074 (2001)

25. K. M. Cuffey, F. Vimeux, Nature 412, 523 (2001).

26. F. Vimeux, K. Cuffey, J. Jouzel, Earth Planet. Sci. Lett. 203, 829 (2002)

27. G. Hoffmann, J. Jouzel, S. J. Johnsen, J. Geophys. Res. 106, 14265 (2001).

28. C. A. Shuman et al., J. Geophys. Res. 100, 9165 (1995).

29. G. Hoffmann, M. Stievenard, J. Jouzel, J. W. C. White, S. J. Johnsen, in Isotope Techniques in the Study of Environmental Changes (International Atomic Energy Agency, Vienna, 1998), pp. 591-602.

30. M. Kageyama, P. J. Valdes, Geophys. Res. Lett. 27, 1515 (2000).

31. C. Waelbroeck et al., Quat. Sci. Rev. 21, 295 (2002).

32. K. M. Cuffey, G. D. Clow, J. Geophys. Res. 102, 26383 (1997).

33. Z. Liu, E. Brady, J. Lynch-Stieglitz, Paleoceanography 18, 10.1029/2002PA000819 (2003)

34. E. Cortijo et al., Paleoceanography 14, 23 (1999).
35. M. F. Loutre, D. Paillard, F. Vimeux, E. Cortijo, Earth Planet. Sci. Lett. 221, 1 (2004)

36. E. Cortijo, L. D. Labeyrie, M. Elliot, E. Balbon, N. Tisnerat, Quat. Sci. Rev. 19, 227 (2000).

37. CLIMAP, in GSA Map and Chart Series, MC-36 (Geological Society of America, Boulder, CO, 1981).

38. E. Cortijo et al., Earth Planet. Sci. Lett. 146, 29 (1997).

39. K. Fuhrer, E. W. Wolff, S. J. Johnsen, J. Geophys. Res. 104, 31043 (1999).

40. L. C. Peterson, G. H. Haug, K. A. Hughen, U. Röhl, Science 290, 1947 (2000).

41. J. Chappellaz et al., Nature 366, 443 (1993).

42. North Greenland Ice Core Project Members, Nature 431, 147 (2004).

43. A. Berger, Celest. Mech. 15, 53 (1977).

44. A. M. Grachev, J. P. Severinghaus, J. Phys. Chem. 107, 4636 (2003).

45. This work is a contribution to the Greenland Ice Core Project (GRIP) organized by the European Science Foundation. We thank the GRIP scientists, logistics support, and core processors. We also thank the science foundations in Belgium, Denmark, France, Germany, Iceland, Italy, Switzerland, and the UK as well as the EC program. LSCE $\delta D$ analyses were funded by CEA and Programme National d'Etude de la Dynamique du Climat. We thank E. Cortijo, U. von Grafenstein, F. Vimeux, M. Kageyama, and two anonymous reviewers for discussions on the method and suggestions to improve the manuscript.

\section{Supporting Online Material}

www.sciencemag.org/cgi/content/full/309/5731/118/ DC1

Materials and Methods

Table S1

10 December 2004; accepted 20 May 2005

10.1126/science. 1108575

\title{
A Magnetic Nanoprobe Technology for Detecting Molecular Interactions in Live Cells
}

\section{Jaejoon Won, ${ }^{1}$ Mina Kim, ${ }^{1}$ Yong-Weon $\mathrm{Yi}^{1}{ }^{1}$ Young Ho Kim, ${ }^{2}$ Neoncheol Jung, ${ }^{2}$ Tae Kook Kim ${ }^{1 *}$}

\begin{abstract}
Technologies to assess the molecular targets of biomolecules in living cells are lacking. We have developed a technology called magnetism-based interaction capture (MAGIC) that identifies molecular targets on the basis of induced movement of superparamagnetic nanoparticles inside living cells. Efficient intracellular uptake of superparamagnetic nanoparticles (coated with a small molecule of interest) was mediated by a transducible fusogenic peptide. These nanoprobes captured the small molecule's labeled target protein and were translocated in a direction specified by the magnetic field. Use of MAGIC in genome-wide expression screening identified multiple protein targets of a drug. MAGIC was also used to monitor signal-dependent modification and multiple interactions of proteins.
\end{abstract}

Modern medicine faces the challenge of developing safer and more effective therapies. However, many drugs currently in use were identified without knowledge of their molecular targets $(1,2)$. Bioactive natural products are an important source of drug leads, but

1Department of Biological Sciences, Korea Advanced Institute of Science and Technology, Daejeon 305701, Korea. ${ }^{2}$ CGK Co. Ltd., Daejeon 305-701, Korea.

*To whom correspondence should be addressed. E-mail: tkkim@kaist.ac.kr their modes of action are usually unknown (2). Elucidation of their physiological targets is essential for understanding their therapeutic and adverse effects, thereby enabling the development of second-generation therapeutics. Moreover, the discovery of novel targets of clinically proven compounds may suggest new therapeutic applications (3). Target identification (ID) is also important in chemical biology, where high-throughput screening is used to identify small molecules with a desired phenotype $(4,5)$. Despite the great benefits of such 


\section{Science}

\section{GRIP Deuterium Excess Reveals Rapid and Orbital-Scale Changes in Greenland Moisture Origin}

V. Masson-Delmotte, J. Jouzel, A. Landais, M. Stievenard, S. J. Johnsen, J. W. C. White, M. Werner, A. Sveinbjornsdottir and K. Fuhrer

Science 309 (5731), 118-121.

DOI: $10.1126 /$ science. 1108575

ARTICLE TOOLS

SUPPLEMENTARY MATERIALS

REFERENCES

PERMISSIONS http://science.sciencemag.org/content/309/5731/118

http://science.sciencemag.org/content/suppl/2005/06/28/309.5731.118.DC1

This article cites 36 articles, 5 of which you can access for free http://science.sciencemag.org/content/309/5731/118\#BIBL

http://www.sciencemag.org/help/reprints-and-permissions 